\title{
Exploration on Teaching Reform of Rural Landscape Planning and Design Under the Background of Rural Revitalization
}

\author{
Qiao $\mathrm{Yu}^{*}, \mathrm{Han} \mathrm{Gu}$, Xiaohong Lai \\ College of Architecture and Urban Planning, Chongqing Jiaotong University \\ *Corresponding author.Email:791711905@qq.com
}

\begin{abstract}
Under the background of the national rural revitalization strategy, the course of rural landscape planning and design has been given a higher direction and is an important teaching type of landscape planning and design series courses. Based on the cognition of rural characteristic value and practical problems, this paper puts forward the teaching objectives and teaching points of rural landscape planning and design course, and takes Zhongba Island, Jiangjin, Chongqing as an example to explore the teaching practice.
\end{abstract}

Keywords: Rural revitalization strategy, Rural landscape planning and design, Teaching reform, Construction of ecological civilization.

\section{COURSE TEACHING OBJECTIVES UNDER THE BACKGROUND OF RURAL REVITALIZATION}

\subsection{Rural Revitalization Strategy Background}

The rural revitalization strategy was first put forward in 2017. The modernization of agriculture and rural areas are accelerated in accordance with the general requirements of thriving industries, livable ecology, civilized local customs, effective governance and a well-off life. The demolition and construction should not be carried out on a large scale. The preservation of ancient villages, the attention to the local flavor, the preservation of the rural style, the preservation of green mountains and clear waters, and the memory of nostalgia are highlighted.

In 2020, Chongqing put forward the strategic action plan for rural revitalization to build an ecologicallylivable and beautiful countryside, and create a rural living environment.

Rural landscape planning and design is an important teaching type of landscape planning and design courses. Under the background of national rural revitalization strategy, rural landscape planning and design is given a higher direction ${ }^{[1]}$.

\subsection{Course Teaching Objectives}

\subsubsection{Knowledge Level}

Students are encouraged to know the concept and characteristics of rural and the rural landscape, understand and master the theory and method of rural landscape planning and design.

\subsubsection{Ability Level}

Students are trained in rural social investigation and the ability to explore scientific problems. Students are trained to develop comprehensive abilities of rural landscape planning and design, such as engineering practice, critical thinking spirit, communication and expression, and teamwork, to solve complex problems in rural construction.

\subsubsection{Value Level}

Students are trained in cognition of rural ecological, social, cultural and economic values and ecological service functions ${ }^{[2]}$. Students are guided to set up the correct values and scientific concept of rural planning ${ }^{[3]}$. Students' enthusiasm for the study and research of rural planning and construction are enhanced ${ }^{[4]}$. 


\section{TEACHING ESSENTIALS OF RURAL LANDSCAPE PLANNING AND DESIGN COURSE}

\subsection{Cultivate Correct Planning Value Orientation}

\subsubsection{Equality}

In the past, rural areas have been neglected in planning practice ${ }^{[5]}$. Only when we realize that the countryside and the city are equal and believe that the countryside and the city can carry the happy life of human beings, can the countryside be guided into an ideal living environment by the rural landscape planning.

\subsubsection{Take Villagers as Foundation}

Rural area has the dual attributes of historical and cultural heritage and real living environment, and the residents of the village are the owners of the rural area. Therefore, rural landscape planning must serve the interests of residents ${ }^{[6]}$.

\subsubsection{Adjust Measures to Local Conditions}

Rural landscape planning should avoid "one village in a thousand", and emphasize the differences of natural region, history and humanities, social economy and rural population, so that rural people can live in harmony with nature, traditional culture can be inherited, and individual and society can progress together.

\subsection{4. "Process Planning" is Greater than "Blueprint planning"}

Rural landscape planning is not to draw a static ideal blueprint, but to work with the local government, grassroots organizations and villagers to find a way to revitalize rural development. The meaning of "process planning" is greater than that of "blueprint planning", and the effectiveness of "action planning" is better than that of rural landscape overall planning.

\subsection{Theoretical Cognition is Integrated with Design Practice}

\subsubsection{Progressive Integration of Theories Related to Rural Landscape}

The course of rural landscape planning and design covers theoretical knowledge of multiple disciplines such as society, history, culture, economy and ecology, but students cannot understand and apply many theoretical knowledge in a short time, so it is necessary to prioritize theories of these related disciplines. For example, ecology should be placed in the first place in theoretical cognition, ecology priority should be taken as the first principle of planning, and then theories of rural society, history and culture should be gradually introduced into teaching.

In the preliminary analysis stage, students should be inspired to cross and integrate these theoretical knowledge, and analyze their synergies and contradictions in this field, so as to encourage students to form their own open conclusions.

\subsubsection{Principles of Rural Landscape Planning Based on Theoretical Cognition}

The multiple paths of rural landscape construction are applied. For villages with large scale and good conditions for comprehensive development, the construction of public space landscape and the allocation of service facilities should be strengthened. For villages with rich historical resources and beautiful pastoral scenery, we should strengthen the protection of traditional villages and highlight their rural characteristics. For ordinary villages, environmental improvement and landscape upgrading should be strengthened. Different types of villages should have different rural landscape construction paths.

The rural landscape planning need "Seek common ground while reserving differences". "Seeking common ground" means that rural landscape planning still needs to use the basic planning principles and design basis of urban areas. "Reserving differences" refers to mastering and applying theories and methods of rural landscape planning that are different from those of cities.

Sustainable planning and design on the basis of protection is pivotal. In the planning process, the historical culture, local characteristics and ecological environment of rural areas should be fully understood and retained to the greatest extent. Only proper development based on protection can obtain good social effect and higher economic benefit.

\section{TEACHING PRACTICE OF LANDSCAPE PLANNING AND DESIGN OF TRADITIONAL VILLAGES IN ZHONGBA ISLAND, JIANGJIN}

\subsection{Basic Overview of Zhongba Island as the Traditional Village}

Zhongba Island is an island in the center of the river surrounded by water located in the southwest of Shima Town, Jiangjin District, Chongqing. It has the reputation of "the largest island from the Yangtze River to Chongqing". Zhongba island has the rich natural resources and historical cultural resources. It has 
characteristic landscape elements like sugarcane fields, century-old longan trees, wetland scenery, colorful stone beach, patches of grass sea, ancient agricultural residence, characteristic culture. Zhongba Island has the natural ecological beauty of island, the beauty of rural village and the beauty of the human history.

\subsection{Teaching Content Framework of "Theory + Practice"}

Rural landscape is a countryside landscape with obvious rural settlement characteristics based on natural landscape and agricultural production ${ }^{[8]}$. The practice of rural landscape planning and design should be based on the theoretical cognition of various rural landscape, such as landscape ecology, productive landscape, rural sociology, rural geography, cultural landscape heritage and other theories ${ }^{[9,10]}$.

Only by understanding these theories can we have a more scientific cognition of the rural landscape, and then carry out the corresponding reasonable rural landscape planning and design practice (Table 1).

Table 1. The teaching content framework of "theory + practice" in rural landscape planning and design

\begin{tabular}{|l|l|l|}
\hline Rural landscape type & Cognitive theories & Design practice \\
\hline Natural ecological landscape & Landscape ecology, River ecology & $\begin{array}{l}\text { Ecological space structure, Ecological } \\
\text { protection and restoration }\end{array}$ \\
\hline Agricultural production landscape & $\begin{array}{l}\text { Theory of productive landscape and } \\
\text { agricultural multiple function }\end{array}$ & $\begin{array}{l}\text { Planning and layout of agriculture and forestry } \\
\text { industry }\end{array}$ \\
\hline Rural architectural landscape & $\begin{array}{l}\text { The theory of traditional dwellings } \\
\text { architecture }\end{array}$ & $\begin{array}{l}\text { Rural building style control, Rural public } \\
\text { building design }\end{array}$ \\
\hline Rural Life Landscape & Rural sociology, Rural geography & $\begin{array}{l}\text { Public service facilities and public space } \\
\text { planning, Activity planning }\end{array}$ \\
\hline Historical and cultural landscape & $\begin{array}{l}\text { Cultural landscape heritage, Cultural history } \\
\text { theory }\end{array}$ & $\begin{array}{l}\text { Planning for historical and cultural protection } \\
\text { and utilization }\end{array}$ \\
\hline
\end{tabular}

\subsection{Design Tasks of Each Stage}

The general task requirements of Zhongba Island landscape planning include the preserved village pattern, repaired traditional buildings, the protected historical environment elements and the improved living environment.
Four stages of the task are as follows: value and problem identification, direction and goal establishment, master planning and design, architectural style control and detailed landscape design (Table 2).

Table 2. The task requirements of rural landscape planning and design course

\begin{tabular}{|c|c|c|c|}
\hline Stage of course & Week & Mission requirements & Achievement content \\
\hline \multirow{2}{*}{$\begin{array}{l}\text { The first stage } \\
\text { Values and problems } \\
\text { identification }\end{array}$} & 1 & $\begin{array}{l}\text { Site research, analysis of related policy, } \\
\text { planning and excellent case }\end{array}$ & \multirow{2}{*}{$\begin{array}{l}\text { A3 text: } \\
\text { Analysis of location, road, topography, } \\
\text { ecological sensitivity, landscape resources, } \\
\text { current landscape zoning }\end{array}$} \\
\hline & 2 & $\begin{array}{l}\text { Analyze the site situation, summarize } \\
\text { current problems and characteristics }\end{array}$ & \\
\hline \multirow{2}{*}{$\begin{array}{l}\text { The second stage } \\
\text { Direction and goals } \\
\text { establishment }\end{array}$} & 3 & $\begin{array}{l}\text { Rural landscape special direction based on } \\
\text { problems and features }\end{array}$ & \multirow{2}{*}{$\begin{array}{l}\text { A3 text: } \\
\text { Case study, vision, planning objectives, industrial } \\
\text { planning, spatial strategy, project staff, etc. }\end{array}$} \\
\hline & 4 & $\begin{array}{l}\text { Establish planning objectives, form } \\
\text { technical paths and strategies }\end{array}$ & \\
\hline \multirow{2}{*}{$\begin{array}{l}\text { The third stage } \\
\text { Overall planning and } \\
\text { design }\end{array}$} & 5 & $\begin{array}{l}\text { Rural landscape overall planning, overall } \\
\text { spatial layout }\end{array}$ & \multirow{2}{*}{$\begin{array}{l}\text { A3 text: } \\
\text { Functional zoning, land use, spatial layout, road } \\
\text { system, public facilities, landscape, recreation, } \\
\text { plants, etc. }\end{array}$} \\
\hline & 6 & $\begin{array}{l}\text { Special content research and planning } \\
\text { design }\end{array}$ & \\
\hline \multirow{2}{*}{$\begin{array}{l}\text { The fourth stage } \\
\text { Architectural style } \\
\text { control,detailed } \\
\text { landscape design }\end{array}$} & 7 & $\begin{array}{l}\text { Control building features and formulate } \\
\text { regulation guidelines }\end{array}$ & \multirow{2}{*}{$\begin{array}{l}\text { A3 text: } \\
\text { Architectural style control, node landscape } \\
\text { design(4), waterfront space, ecological } \\
\text { environment design,etc. }\end{array}$} \\
\hline & 8 & $\begin{array}{l}\text { Detailed landscape design, layout } \\
\text { design analysis of important nodes }\end{array}$ & \\
\hline $\begin{array}{l}\text { The fifth stage } \\
\text { Results submitted }\end{array}$ & 9 & Results report & $\begin{array}{l}\text { Report the design results in PPT within } 10 \\
\text { minutes. }\end{array}$ \\
\hline
\end{tabular}

\subsection{Teaching Reform Achievements Display}

After teaching reform and exploration, the course has achieved good teaching effects and teaching results. Most students have submitted relatively complete and excellent results (Figure 1). In addition, the revised and improved design of Zhongba Island village based on course teaching supports the practical achievements of Jiangjin Rural Design Studio. 


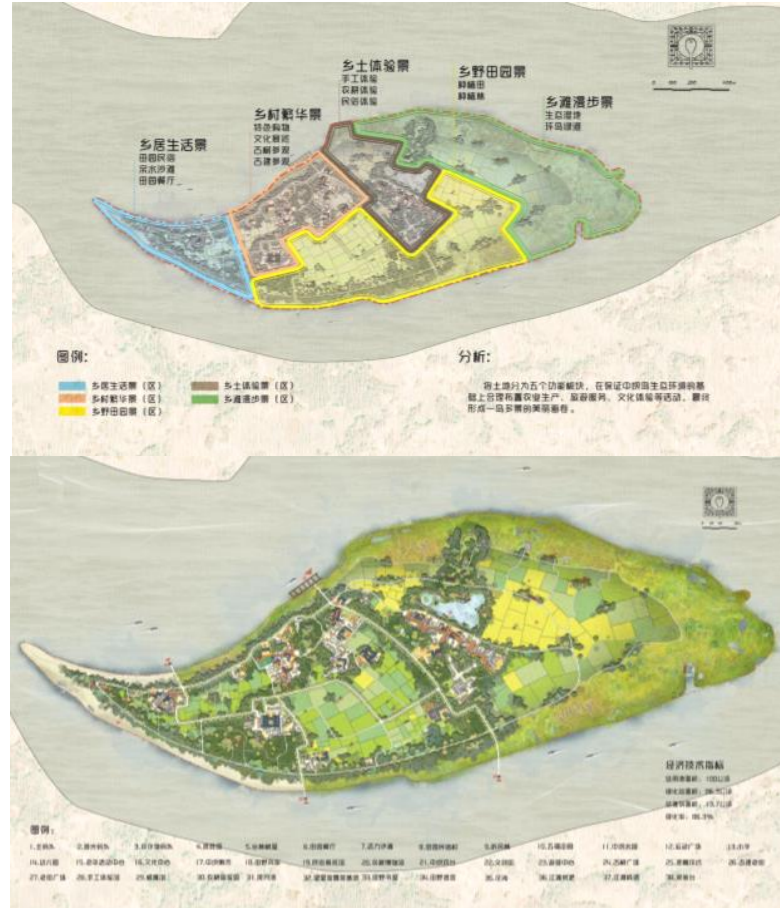

Figure 1 Student achievement drawing display

\section{CONCLUSION}

The course of rural landscape planning and design has been constantly adjusted and improved in terms of teaching content and teaching methods, so as to better strengthen the basic understanding of landscape architecture students about the rural areas and the participation in the practice of rural landscape design, establish correct values and construct scientific planning concepts, and make them become compound professionals.

\section{AUTHORS' CONTRIBUTIONS}

YU Qiao wring the paper and preside over the teaching work. GU Han and LAI Xiaohong participate in teaching work.

\section{ACKNOWLEDGMENTS}

This research was supported by Research Project of Education and Teaching Reform of Chongqing Jiaotong University, "Exploration on Teaching Reform of Largescale Landscape Architecture Planning and Design Course under the Background of Ecological Civilization" (No. 2003020)

\section{REFERENCES}

[1] MA Wenya, Research on rural planning teaching in local colleges and universities under the guidance of rural revitalization strategy, Journal of Higher Education, 2019(22):56-58.
[2] GE Yunyu, LI Fangzheng. Research on the promotion strategy of rural landscape in Beijing based on the identification of dominant ecosystem service. Chinese Landscape Architecture, 2020,36(01):25-30.

[3] CAI Zhongyuan, HUANG Mei, DUAN Degang. Inheritance and practice of rural planning teaching. China Architectural Education, 2016(02):67-72.

[4] QIAO Lili. Thoughts on ideological and political integration in rural landscape design from the perspective of beautiful countryside. Modern Agriculture Research. 2021,27(02):47-48.

[5] ZHANG Yue. Reflections of Studio of Village Survey and Planning. South Architecture, 2009(04):29-31.

[6] XU Chuncheng, WAN Zhiqin. Argument on basic thoughts of traditional village protection. Journal of Huazhong Agricultural University(Social Sciences Edition), 2015(06):58-64.

[7] GUO Chao. Exploration on the teaching reform of landscape architecture planning and design based on visual cognition - take Zhejiang Agriculture and Forestry University of Jiyang Academy“Landscape Architecture”for example. Anhui Agri. Sci. Bull, 2016, 22(10):177-179.

[8] WANG Yuyang. Classification and upgrading strategy of rural landscape in Qianjin Town. Journal of Green Science and Technology, 2021,23(03):15-17.

[9] Zhang Zhonghua, Yan Xiaoxiao. The Strategy of Village Landscape Planning Under the View of Landscape Ecology Theory: The Case of Heiheba Village. 2021,39(03):91-95.

[10] GUO Xiaotong, HAN Feng. Rural Heritage Protection and Sustainable Development Collaboration from the Perspective of Cultural Landscape: Enlightenment from Piedmont Heritage Site, Italy. Landscape Architecture, 2021,28(02): 116-120. 